\title{
Benefits of E-Commerce in Marketing Creative Industrial Products
}

\author{
Jefry Romdonny \\ Swadaya Gunung Jati University, Cirebon, Indonesia \\ mailtojef2010@gmail.com
}

\begin{abstract}
This study aims to determine the benefits of e-commerce for creative economic actors, especially to market their products. The research method uses is qualitative with an analytical and explorative descriptive approach. From the research conducted, the results shows that the use of e-commerce has a positive impact on both producers and consumers. While the benefits for producers are that promotional costs can be reduced so that the selling price can be more competitive. However, the limited ability of human resources to utilize information technology and capital is a major obstacle for micro-entrepreneurs. The role of the regional government, especially the related institutions, is expected to be able to provide guidance and solutions for the development of the creative economy in the region.
\end{abstract}

Keywords : e-commerce; marketing; creative industries

\section{Introduction}

The creative economy in Indonesia is an economic sector that can increase people's incomes, especially from trade, services, and the processing industry. [1] creative and useful for the survival of the local community. One industry that is in great demand by millennials is the snack food industry in the form of spicy chips.

With the advancement of information technology, to facilitate producers to market their products by utilizing e-commerce by using internet networks and consumers it is easy to get the products they need [2], [3]. Sukrat and Papasratorn [4] argue, that the use of information technology using e-commerce benefits both producers and consumers. This opinion is in line with what Sukrat et al. [5] and Saroja [6] that by shopping online it is hoped that consumers can obtain more improved services and producers can increase sales of the products they produce.

How important the use of information technology for the business world, especially for creative economic actors, the authors are interested in knowing more deeply related to the role of e-commerce in marketing creative industrial products, especially snacks. With this research, it is expected to be able to find evidence about the benefits of e-commerce for creative economic activities.

\section{Review of Literature}

\subsection{E-Commerce}

The rapid growth of information technology creates opportunities for businesses to conduct their business online (e-commerce) in an effort to increase customer retention and reduce promotional costs in order to achieve competitive advantage, especially in the retail industry [7], [8]. By utilizing e-commerce, service to consumers will be better especially with regard to information on a product and for producers it will be easier to innovate through web-based internet applications [9], [10], [11]. The results of empirical research conducted by Hommerova \& Kralova [12] and Pilik [13] show that the use of information technology to 
market production through e-commerce is very supportive, especially to reduce the cost of promotion and increase business income.

\subsection{Marketing}

For the business sector, marketing management is one strategy that must be prioritized in addition to the quality of production. This is a basic principle that must be obeyed and implemented by all business actors that are universally applicable. Management of marketing strategies in the era of globalization is very important, especially the use of e-commerce to reach the market widely in the framework of industrial development. [14] This is reinforced by the opinion expressed by Kahn [16], Tsai [17], and Cant et al. [18] that marketing management today must be an integrated part of the company's identity, especially by utilizing facilities from information technology.

From the results of empirical research conducted by Hamill \& Gregory [19] and Poon \& Swatman [20] it can be concluded that the use of e-commerce in a business activity allows the business organization to be able to directly market its products and obtain good new customers from from domestic and international markets.

\section{Research Methods}

This study uses qualitative methods with a descriptive verification approach. The object of research is the processed food industry under the brand @ Kidas (Spicy Deliveries) which is located at Jalan Sadang No.99A RT.03RW.16 Margahayu Tengah Margahayu Bandung West Java 40225, while the research subject is the owner of "@Kidas" which is key informant and employees and researchers as informants.

The types of data collected are primary data obtained through in-depth interviews with information sources (key informants and informants) and supported by secondary data in the form of books and other literature. The data analysis technique uses an interactive qualitative descriptive model in the form of data collection, meaning the data obtained is then analyzed, verified, and explored and conclusions are made.

\section{Results and Discussion}

From the results of the research in the field, the data related to the object of the research are obtained as shown in the picture below:
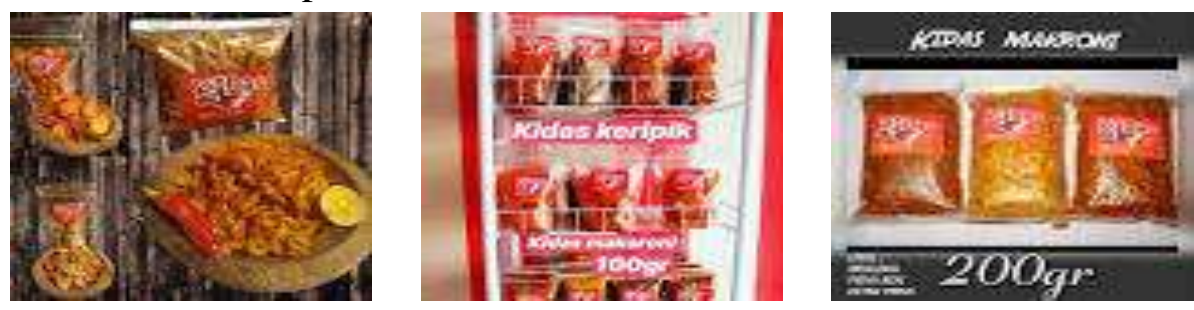

Figure 1. Product @Kidas

From Figure 1 above, it can be explained, that the creative economy business @ Kidas (Spicy Kiriman) is a populist economy that uses information technology through Tokopedia, Bukalapak, Shopee, youtube, and deskgram as a media for promotion and marketing of the 
products it produces. While the number of business transactions after using e-commerce can be seen in the table below.

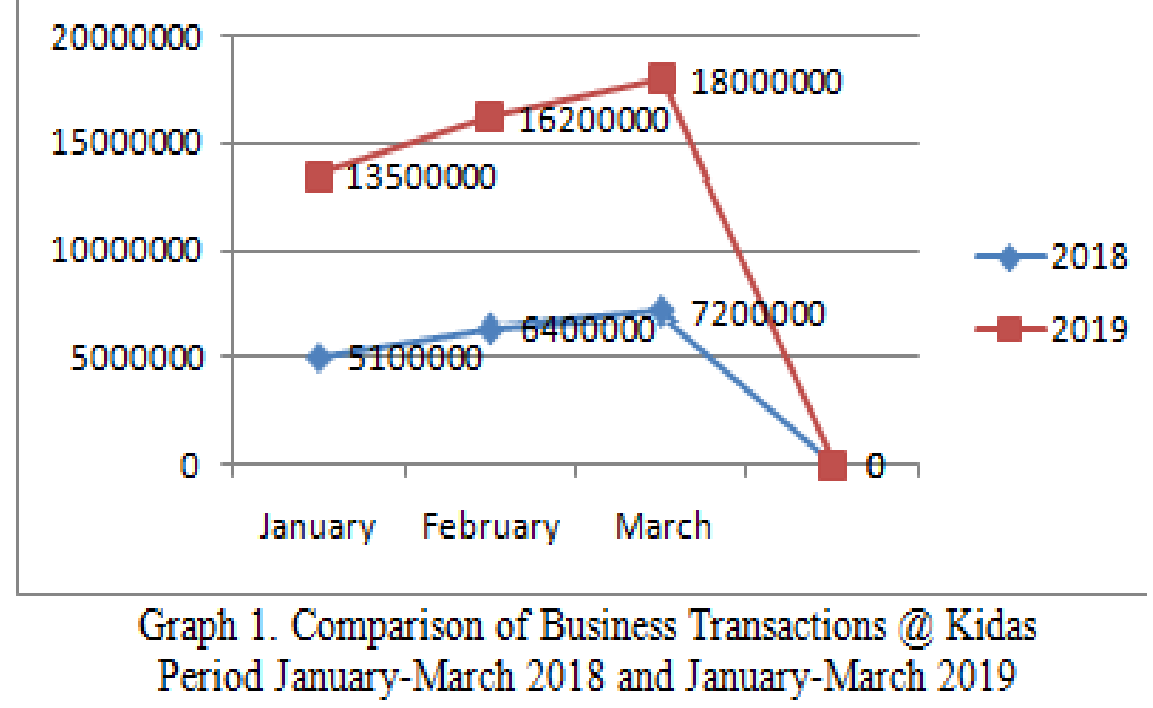

From graph 1 above, it can be explained that the use of e-commerce is very supportive and has a positive and significant impact on increasing the value of @ Kidas business transactions with its customers.

Based on data from research results in the field it can be explained that the benefits of e-commerce for business people, especially creative industries, are very useful and supportive for the development of their business. This is in accordance with the opinion expressed by Aribawa [7] and Kabango et al. [8] that by utilizing e-commerce, creative economic actors can create a positive climate for their business, especially to develop their product marketing and to increase their competitive advantage to be attractive to their customers. While ecommerce for business actors @ Kidas is very helpful for increasing business transactions and this can be seen in graph 1. With the increase in this business transaction, this is in accordance with the opinion expressed by Veronika [14] and Mohapatra [15] that marketing creative economic products must be able to use the right marketing strategies to be widely accepted by consumers in this digital era.

However, some constraints are faced by business people, especially in the mastery of information technology (internet) by their employees and the lack of role of the regional government in relation to guidance and ease in obtaining additional capital from banks.

\section{Conclusion}

[1] M. Al-Amin and S. Maro'ah, "Geliat Usaha Mikro Ibu-Ibu Rumah Tangga Dari Keluarga Miskin Pembutan Abon Bandeng dan Kecap di Gunung Anyar Kota Surabaya," Aksiologiya: Jurnal Pengabdian Kepada Masyarakat, vol. 1, no. 2, pp. 126-134, 2017.

[2] T. Broncekova and D. Bernatova, "Globalizacia a elektronicke podnikanie. E + M," Ekonomie A Management, vol. 3, pp. 105-112, 2005.

[3] T.K. Sung, "E-commerce critical success factors: East vs. West," Technological Forecasting and Social Change, vol. 73, no. 9, pp. 1161-1177, 2006.

[4] Supattana Sukrat and Borworn Papasratorn, "A Maturity Model For C2C Social Commerce 
Business Model," International Journal of Electronic Commerce Studies, vol. 9, no. 1, pp. 27-54, 2018.

[5] Supattana Sukrat, Pruthikrai MahatananKoon, and Borworn Papasratorn, "The evolution of C2C social commerce models," in 11th International Conference of C2C Social Commerce Models, Porto Portugal, 2016.

[6] S. Saroja, "Information technology - Key success factor in retail," Gian Jyoti Journal, vol. 2, no. 1, pp. 221-233, 2012.

[7] Dwitya Aribawa, "E-commerce Strategic Business Environment Analysis in Indonesia," International Journal of Economics and Financial Issues, vol. 6, no. S6, pp. 130-134, 2016.

[8] Christian Mbayo Kabango, Jacobsen Rune, and Andy Veitch, "Factors Influencing E-commerce Development: Implications for the Developing Countries," International Journal of Innovation and Economic Development, vol. 1, no. 1, pp. 59-66, 2915.

[9] Zhiyuan Fang, "E-government in digital era: concept, practice, and development," International Journal of the Computer, the Internet and Management, vol. 10, no. 2, pp. 1-22, 2002.

[10] P.T. Jaeger, "The endless wire: E-government as global phenomenon," Government Information Querterly, vol. 20, no. 4, pp. 323-331, 2003.

[11] Lemuria Carter and France Belanger, "Citizen Adoption of Electronic Government Initiatives," in In the 37th Hawaii International Conference on System Sciences, Hawaii, 2004, pp. 57-63.

[12] D. Hommerova and L. Kralova, "Analyza podpor marketingove činnosti využivanych firmami v Česke republice," E + M M Ekonomie a Management, vol. 12, no. 3, pp. 77-90, 2009.

[13] M. Pilik, "Nove marketingove trendy jako přiležitost zvyšeni vlivu marketingu na dosaženi konkurenčnich vyhod," E + M Ekonomie a Management, vol. 2, pp. 107-119, 2008.

[14] Svatosova Veronika, "The Use of Marketing Management Tools in E-commerce," Acta Universitatis Agriculturae et Silviculturae Mendelianae Brunensis, vol. 63, no. 1, pp. 303-312, 2015.

[15] S. Mohapatra, E-Commerce Strategy. New York, USA: Springer, 2013.

[16] Kenneth B. Kahn, "Functional, multifunctional and cross-functional: Considerations for marketing management," Journal of Marketing Theory and Practice, vol. 17, no. 1, pp. 75-84, 2009.

[17] Shu Pel Tsai, "Corporate marketing management and corporate-identity building," Marketing Intelligence \& Planning, vol. 26, no. 6, pp. 621-633, 2008.

[18] M.C. Cant, J.W. Strydom, C.J. Jooste, and P.J. du Plessis, Marketing Management, 5th ed. Cape Town, South Africa: Juta Academic, 2009.

[19] Jim Hamill and Karl Gregory, "Internet Marketing in the Internationalization of UK SMEs," Journal of Marketing Management, vol. 13, no. 1-3, pp. 9-28, 1997.

[20] Simpson Poon and Paula Swatman, "An Exploratory Study of Small Business Internet Commerce Issues," Information \& Management, vol. 35, no. 1, pp. 9-18, 1999. 